\title{
Soft Tissue Sarcoma Clinical Distant Metastasis TNM Finding v7
}

National Cancer Institute

\section{Source}

National Cancer Institute. Soft Tissue Sarcoma Clinical Distant Metastasis TNM Finding v7. NCI Thesaurus. Code C88467.

A clinical finding about one or more characteristics of soft tissue sarcoma, following the rules of the TNM AJCC V7 classification system as they pertain to distant metastases. 